\title{
REAL PROPERTY LAW: STATE POLICE POWER HELD INSUFFICIENT TO REGULATE REGISTRATION OF EXISTING POSSIBILITES OF REVERTER AND POWERS OF TERMINATION AS CONDITION FOR PRESERVATION
}

\author{
The New York Court of Appeals recently held that the New York \\ Real Property Law, requiring registration of possibilities of re- \\ verter and powers of termination as a condition for their preser- \\ vation, was invalid in its attempted retrospective application. \\ This decision may have persuasive impact beyond New York, as \\ most marketable title acts contain a similar provision.
}

$I_{N}$

N RECENT YEARS several states have enacted statutes to promote the marketability of land. ${ }^{1}$ Although these statutes arguably violate sections of the federal Constitution and of the individual state constitutions, only a few courts have addressed themselves

${ }^{1}$ Fla. Stat. $\$ 689.18$ (1963); Ill. Rev. Stat. ch. 30, $\$ 37$ e (1965); Ill. Rev. Stat. ch. 83, $\S 10$ (a) (1965); IND. ANN. STAT. $\$ \S 56-1101$ to -1110 (Supp. 1965); IowA CODE $\S 614.17$ (1962); H.F. 115, 1 IOWS LEG. SERv. 1965 at 19 (March 15, 1965); Kx. Rev. STAT. $\$ \S 381.221-.223$ (1960); MAss. ANN. LAws ch. 260, $\$ 32$ (1956), and ch. $184, \S \S 19,26-30$ (Supp. 1964); Mich. STAT. ANN $\$ \S 26.1271-.1279$ (1953), as amended, Mich. Stat. Release No. 15 at 1420; Minn. Stat. ANN. $\$ 541.023$ (Supp. 1964); Neb. REv. Stat. $\$ \$ 76-288$ to -298 (1958); NEb. REv. Stat. $\$ 76-2102$ (Supp. 1963); N.Y. REAL Prop. Law § 345 (Supp. 1965); N.C. Gen. Stat. § 1-42.I (7 Adv. Leg. Serv. 1965); N.D. CENT. CODE $\$ \S ~ 47-19 A-01$ to -11 (1960); OHIo Rev. CODE ANN. \$§ 5301.47-.55 (Page Supp. 1964); S.D. CODE $\$ \S 51.16 B 01-.16 B 14$ (Supp. 1960); UTAH CODE ANN. $\$ \$ 57-9.1$ to -9-10 (1963), as amended, Utah Code ANN. \$ 57-9-6 (Supp. 1965); Wis. Stat. \$ 330.15 (1963), as amended, Wis. Laws 1965, ch. 66, $\S 2$ (amending section number to $\S$ 893.15).

The promotion of the alienability of land has long been accepted public policy. Recording systems were adopted in the furtherance of this policy and operated to remove many of the uncertainties involved in land transactions under the common law. Basye, Trends and Progress-The Marketable Title Acts, 47 Iows L. REv. 261-63 (1962). However, this purpose has been subverted hy the system itself. Searches arc tedious and cumbersome, and many ancient interests which have long been forgotten by the parties remain on the records as notice to a future purchaser. Economic development of the land is thus frequently impaired. This situation has caused growing concern, and many states have undertaken reforms. Id. at 264. Sce Aigler, Constitutionality of Marketable Title Acts, 50 MrcH. L. REv. 185-86 (1951).

One frequently employed reform is the adoption of a "marketable title" act-so denoted because several early versions of this type of statute undertook to define what titles should be accepted as merchantable. This reform was generally tailored to one aspect of the problem-the reduction in the period of title search and ex. amination. BasYe, Clearing LAND TrtLes $\$ 171$, at 260 (1953). It soon became evident that this reform alone would not solve the broad problem of promoting the economic utilization of land. Sce Smes \& Taylor, The Improvenent of Convexancing dy LEGISLATION 4-6 (1960).

Under the usual recording system, the recording of an interest will give notice of its existence for all time; therefore, an effort to increase marketability of land must 
to a determination of their validity. ${ }^{2}$ The most recent case to focus on the question is Board of Educ. v. Miles, ${ }^{3}$ in which the New York Court of Appeals held a New York marketability statute invalid. That statute, section 345 of New York's Real Property Law, provides that:

... a condition subsequent or special limitation restricting the use of land and the right of entry or possibility of reverter created thereby shall be extinguished and become unenforceable, either at law or in equity, ... unless within the time specified in this section a declaration of intention to preserve it is recorded . . . 4

The law, enacted in 1958,5 provided that if the special limitation or condition subsequent was created prior to 1931, the declaration should be recorded prior to September 1, $1961 .^{6}$

The special limitation giving rise to the instant case was effectuated in 1853, when land was conveyed to the Walton Academy. ${ }^{\top}$ The conveyance was subject to a special limitation restricting the land to use for school purposes, with the proviso that if it ever ceased to be so used, it would revert to the grantor and his heirs. In 1962, the Board of Education, successor to the Walton Academy, ceased using the land for school purposes. The defendants, heirs and devisees of the grantor, then claimed title to the land by virtue of the reversion, and the Board of Education instituted action seeking a determination of the claim. ${ }^{8}$

include a method designed to remove encumbrances in the current record as well as preventing similar ones from being established in the future. It is this retrospective effect which raises the questions of constitutionality. Id. at 253 .

"Marketability acts," as the term is employed in this note, includes not only "marketable title" acts, but the other retrospective legislation aimed at the same ultimate goal-the promotion of full economic utilization of land.

${ }^{3}$ See Biltmore Village, Inc. v. Royal, 71 So. 2d 727 (Fla. 1954); Trustees of Schools of Township No. I v. Batdorf, 6 Ill. 2d 486, 130 N.E.2d 111 (1955); Tesdell v. Hanes, 248 Iowa 742, 82 N.W.2d 119 (1957); Wichelman v. Messner, 250 Minn. 88, 83 N.W.2d 800 (1957); Board of Educ. v. Miles, 15 N.Y.2d 364, 207 N.E.2d 181, 259 N.Y.S.2d 129 (1965).

${ }^{3} 15$ N.Y.2d 364, 207 N.E.2d 181, 259 N.Y.S.2d 129 (1965).

- N.Y. Real Prop. Law \& 345 (I) (Supp. 1965).

N.Y. Sess. Laws 1958, ch. 865, at 1918-22.

${ }^{6}$ N.Y. Real Prop. Law $\$ 345$ (4) (Supp. 1965). The general approach of the law was to require the notice to be filed between twenty-seven and thirty years after creation of a condition or limitation, with subsequent renewal of this notice every ten years. Ibid. Interests which would have been more than thirty years old at the effective date of the act would not automatically be lost, but could be preserved by recording. Law Revision Comm'n, Report, N.Y. LEGis. Doc. No. 65, at 231-32 (1958). See note 32 infra. This approach has been suggested by several commentators. See, e.g., Simrs \& TAYLoR, op. cit. supra note 1, at xix-xx; Aigler, supra note 1, at 199-201.

${ }^{7}$ Brief for Respondent, p. 2; Brief for Appellant, p. 3.

${ }^{8}$ I5 N.Y.2d at 367,207 N.E.2d at 183,259 N.Y.S.2d at 131-32. 
Since this limitation was created prior to 1931, it could be preserved under the New York statute only by the filing, on or before September 1, 1961, of a "declaration of intention to preserve" it. ${ }^{0}$ Although the defendants had in fact filed such a declaration, they had failed to do so until April, 1962.10 Hence, when the lower court applied the New York marketability statute, ${ }^{11}$ it held that by failing to conform to the statute's requirements the defendants had lost their right to claim the land under the reverter. The defendants attacked the statute as an unconstitutional impairment of contract and as a denial of due process, ${ }^{12}$ but the lower court held that the law was a "reasonable and salutory public control of the use of a peculiar form of property which, without regulation, could adversely affect free alienability and development of land," and was therefore constitutionally valid on both the impairment and due process

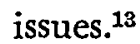

The New York Court of Appeals reversed the court below, holding that inasmuch as the statute attempted to add to the defendants' duties under an existing contract for the sale of land, it was an impairment of their contract rights. ${ }^{14}$ The court recognized the fact that the prohibition against impairment of contracts by a state is not absolute, and that retrospective state laws impairing vested rights may be constitutional if adopted in pursuance of the police power. ${ }^{15}$ However, this requisite nexus with a valid use of the police power was held to be lacking, and therefore the statute's impairment of contract rights was deemed to be in contravention of the contract clause. ${ }^{16}$

\footnotetext{
${ }^{8} I d$. at 373,207 N.E.2d at 186,259 N.Y.S.2d at 136-37.

${ }^{10}$ Board of Educ. v. Miles, 18 App. Div. 2d 87, 89, 238 N.Y.S.2d 766, 768 (1963).

${ }^{11}$ The case originated in the Supreme Court-Appellate Division pursuant to N.Y. Sess. Laws 1946, ch. 316, $\S 1$, and N.Y. Sess. Laws 1930, ch. 87, § 1 (now N.Y. Crv. Prac. LAw Rule 3222), which provides that in cases in which there is no dispute of fact the parties may submit a stipulation of agreed facts. The case may then be decided directly by the Appellate Division.

${ }^{12}$ The law was alleged to have violated U.S. ConST. art. I, § 10; U.S. ConsT. amend. XIV; N.Y. CoNst. art. 1, § 6. Brief for Respondent, p. 3, Brief for Appellants, p. 5. Neither the decision of the Appellate Division nor that of the Court of Appeals made specific reference to the constitutional provisions. Since the New York constitution does not contain a "contract's clause" the courts' decisions on that point must be based on their construction of the federal Constitution. There was no indication which provision the Miles court was purporting to interpret.

${ }^{13}$ Board of Educ. v. Miles, 18 App. Div. 2d 87, 93, 238 N.Y.S.2d 766, 772 (1963).

${ }_{14} 15$ N.Y.2d at 373,207 N.E.2d at 186,259 N.Y.S.2d at 136.

${ }^{15}$ Id. at 372,207 N.E.2d at 184, 259 N.Y.S.2d at 133-34.

${ }^{10} I d$. at $370-71,207$ N.E.2d at 185, 259 N.Y.S.2d at 134-35.
} 
In adjudging the constitutionality of this statute the court focused upon the purposes for which a state's legislation may permissibly effect impairment of private contracts. The court noted that "the prevention of fraud against subsequent purchasers has been generally recognized as a foundation on which the police power depends in voiding prior unrecorded conveyances . . ." 17 The court concluded that since the New York marketability statute was not drawn to protect purchasers in good faith, the act could not be upheld on the familiar fraud-prevention grounds. From this it was reasoned that if the recording requirements of section 345 were to be sustained, it would have to be on a theory similar to that of title registration acts which do not depend for their validity on the saving grace of prevention of fraud on innocent third parties. ${ }^{18}$ However, the court noted that the purpose of section 345 was different from that of title registration laws, which are intended to protect valid claims, not to dispose of valid but inconvenient ones..$^{19}$ The court also dealt with the contention that a marketability act could be upheld as a statute of limitation. ${ }^{20}$ In this respect the court noted that since the reverter had not matured when it was barred by the statute, the persons who would have to register it would not be ascertained. ${ }^{21}$ Thus, the statute in effect would bar "the remedy before the right to enforce it has matured . . .."22 Therefore, instead of "limiting" a right, it extinguished it altogether.

Thus, the court concerned itself with two basic arguments in the Miles case. First, the court felt that the law could not be upheld as a valid use of the legislature's power to enact statutes of limitation. Second, the court concluded that the legislation could not be sustained as a valid use of the police power since the requisite protective purpose was lacking. The broader question of due process is implicit in both of these issues. ${ }^{23}$ The persuasiveness of the Miles

${ }^{17}$ Id. at 369,207 N.E.2d at 184,259 N.Y.S.2d at 134.

${ }^{18} I d$. at $370-71,207$ N.E.2d at 184-85, 259 N.Y.S.2d at 134-35. See text accompanying notes 28-29 infra. The court noted that the statute purports to operate on the original parties to the transaction and their successors in interest, "without the justification of protecting the intervening rights of third persons." Id. at 371, 207 N.E. at 185, 259 N.Y.S.2d at 135. It appears, however, that any such statute is designed to protect buyers also.

${ }_{10} \mathrm{Id}$. at $371-72,207$ N.E.2d at $185-86,259$ N.Y.S.2d at 135-36.

${ }^{20} \mathrm{Id}$. at $372-74,207$ N.E.2d at 186-87, 259 N.Y.S.2d at 136-37.

${ }^{2 x}$ Id. at 373,207 N.E.2d at 186,259 N.Y.S.2d at 137 . See text accompanying notes 33-34 infra. See generally SImEs, Future INTEREsts $\$ 724$ (1936).

22 I5 N.Y.2d at 374,207 N.E.2d at 187,259 N.Y.S.2d at 137.

${ }^{23}$ Due process acts as a restriction on the form of a statute of limitation which a 
decision in jurisdictions with untested marketability statutes may well depend upon the court's treatment of these three issues.

Marketable title acts have been characterized as embodying elements of recording laws, curative acts, and statutes of limitation. ${ }^{24}$ Although the New York court's opinion did not discuss the curative aspects of the legislation, a reading of the challenged statute shows that it was not intended to correct unintentional defects in a conveyance to make it correspond with the actual wishes of the parties. ${ }^{25}$ The court instead dealt with the more analogous theories of recording acts and statutes of limitation.

The court's negation of the analogy between the marketable title acts and recording laws seemingly fails to note that recording acts may serve more than the single purpose of preventing frauds. The enactment of recording laws may have several objectives. Cer-

state may enact. See note 32 infra. Likewise, due process is both a limitation on, and is limited by, a state's use of the police power. See Lambert v. California, 355 U.S. 225,228 (1957).

The approach adopted by the Court of Appeals in Miles appears to have involved an unarticulated decision as to the limits placed on the police power by due process, and then an application of the standard thus obtained to the facts of the case. Such an approach is unfortunate, since a determination of due process requirements usually involves a careful weighing of the various factors. See Brock v. North Carolina, 344 U.S. 424, 427-28 (1953). The decision in the Miles case will afford scant precedential guidance in future litigation to the extent that there is no indication of the factors considered by the court in finding a due process deficiency in the statute.

24 See Wichelman v. Messner, 250 Minn. 88, 106.07, 83 N.W.2d 800, 816 (1957). In that case the Minnesota court stated that a marketable title act is similar to a curative act since it may "correct certain defects which have arisen in the execution of instruments" in the muniments of title, id. at 106, 83 N.W.2d at 816; that it is similar to a recording act because "it requires notice to be given to the public" of the existence of certain conditions which may affect the land's marketability, ibid.; and that it is like a statute of limitations in that unless the notice is filed, "a right of action to enforce any right, claim, or interest" is not preserved, whether the claim or interest is "mature or immature and whether it is vested or contingent." Id. at 107, 83 N.W.2d at 816. Commentators have also noted these analogies. See Simes \& TAYlor, op. cit. supra note 1, at 4; Aigler, Marketable Title Acts, 46 U. MLAMI L. REv. 47, 57 (1958).

${ }^{25}$ Sce text accompanying note 4 supra. The act does not purport to effectuate the ultimate intentions of the contracting partics. Instead, it disregards the plain import of the language of a conveyance and subjects it to the desired public policy. Thus, any "curative" effect appears to be purely incidental. But see Wilson v. Iseminger, 185 U.S. 55 (1902) (discussed in note 32 infra), where a similarly broad statute of limitations was upheld. The Supreme Court in Wilson quoted with apparent approval a statement regarding conditions existing at the time of the act there in question, and discussed the statute from a "curative" standpoint. Id. at 60.61.

Although the incidental curative effect may be insufficient support for the validity of such a statute, it may affect the decision of a court in an otherwise un. certain case. See Wilson v. Iseminger, supra; Wichelman v. Messner, supra note 24, at 106-07, 83 N.W.2d at 816 . 
tainly one of these is the prevention of frauds; but another has long been the promotion of reliance on the public record, ${ }^{26}$ thus generally lessening the risks of real estate transactions and resulting in a more economic use of land. It is this latter purpose which gives rise to the analogy between marketable title laws and recording acts; yet this purpose was apparently ignored by the New York court. ${ }^{27}$

${ }^{20}$ An early Massachusetts law illustrates the multi-purpose nature of recording laws. It stated that it was passed to avoid fraudulent conveyances, "and that every man may know what estate or interest other men may have in any houses, lands or other heriditamets [sic] they are to deal in . . . Mass. LAws \& Liberties 1648, at 13 (1929).

Professor Corwin Johnson states that the clear, general purpose of recording laws is the creation of a public record. He then lists four more specific purposes: (1) "to enable interested persons ... to ascertain" the state of a title; (2) "to furnish admissible evidence of title" in disputes; (3) "to enable owners of equitable interests to protect" them by giving notice to subsequent vendees; and (4) "to modify the traditional case-law doctrine that purchasers . . . get no better title than the transferor owned." Johnson, Purposes and Scope of Recording Statutes, 47 Iowa L. REv. 231 (1962).

${ }^{27}$ The distinguishing characteristic of marketability legislation is its ultimate goal of promoting the full economic utilization of land. However, in seeking the attainment of this goal, the legislatures must consider many factors such as the current status of the state's property law, both statutory and judicial, and par. ticular local conditions in need of a remedy. Since factors of this kind vary from state to state, it is not surprising that the final form of statute chosen by the various state legislatures is not identical. This diversity among the statutes manifests itself in several ways. For example, each legislature tends to describe the goal of its statute in terms of the more particular problems considered. For purposes of differentiation, this stated goal may be termed an "intermediate" one since the ultimate goal, though unarticulated, seldom differs from state to state.

While marketability acts may assume many forms, the bulk of the acts may be considered as falling into two groups. The first group generally follows the concept of the Model Marketable Title Act which provides:

"Subject to the matters stated in Section 2 hereof, such marketable record title shall be held by its owner and shall be taken by any person dealing with the land free and clear of all interests, claims or charges whatsoever, the existence of which depends upon any act, transaction, event or omission that occurred prior to the effective date of the root of title. All such interests, claims or charges, however denominated, whether legal or equitable, present or future, whether such interests, claims or charges are asserted by a person sui juris or under a disability, whether such person is within or without the state, whether such person is natural or corporate, or is private or governmental, are hereby declared to be null and void." Model MARKeTABLE TitLe ACT § 3; Simes \& TAYLoR, op. cit. supra note 1 , at $7-8$.

Such statutes have as their intermediate goal a reduction in the period of title search and examination. In this regard, the analogy to the recording act is clear. Despite the conservative tone of the New York court, most courts would probably find little difficulty in upholding the burden imposed by statutes of the Model Act group since it is the same as that imposed under the already familiar recording acts. Statutes of this type include the following: ILx. REv. STAT. ch. 83, § 10 (a) (1965); IND. ANN. STAT. § 56-1101 to -1110 (Supp. 1965); IOWA CoDE $\S 614.17$ (1962); Mass. ANn. Laws ch. 184, $\$$ 26-30 (Supp. 1964); Mrch. STat. ANN. $\S \S 26.1271-.1279$ (1953), as amended, Mich. StatuTe Release No. 15, at 1420; MiNN. 
Recording laws may be upheld in New York solely on the basis of fraud prevention, ${ }^{28}$ but other states have recognized their multipurpose nature..$^{20}$ The authorities cited in Miles do establish that the prevention of fraud is a sufficient basis for enacting recording laws. ${ }^{30}$ However, the Miles opinion indicates that it is a necessary element of such legislation. ${ }^{31}$ To the extent that this reasoning is rejected by other states which recognize purposes other than the pre-

Stat. AnN. $\$ 541.023$ (Supp. 1964); NEb. Rev. Stat. $\$ \S 76-288$ to -298 (1958); N.D. CENT. CODE $\S \S 47-19 A-01$ to -11 (1960); OHIo Rev. CODE ANN. $\S \S 5301.47-55$ (Pagc Supp. 1964); S.D. CODE $§ \S 51.16 B 01-.16 B 14$ (Supp. 1960); UTAH CODE ANN. \$§ 57-9.1 to $-9-10$ (1963), as amended, UTAII CoDE ANN. § 57-9-6 (Supp. 1965); Wis. STAT. § 330.15 (1963), as amended, Wis. Laws 1965, ch. 66, $\S 2$ (amending section number to $\S 893.15)$.

A second group of states may be represented by the New York law involved in the principal case. See text accompanying note 4 supra. These acts share with the first group the ultimate purpose of promoting the full economic utilization of land. However, their intermediate goal is the regulation of specific types of property interests. There is no sound analogy supporting the burden imposed by these marketability statutes and the burden imposed by recording laws if one looks merely at the intermediate purpose. However, in terms of the ultimate purpose of the laws, the analogy is present. Statutes of this type include the following: Fla. STAT. \$ 689.18 (1963); Ill. REv. Stat. ch. 30, § 37e (1965); H.F. 115, 1 Iowa Leg. SERv. 1965 at 19 (March 15, 1965); KY. REv. STAT. \$ 381.221-.223 (1960); MAss. ANN. LAws ch. 260, $\$ 32$ (1956), and ch. 184, $\$ 19$ (Supp. 1964); Neb. Rev. Stat. $\S 76-2102$ (Supp. 1963); N.Y. Real Prop. Law § 345 (Supp. 1965); N.C. Gen. Stat. \$ 1-42.1 (7 ADv. LEG. SERv. 1965).

The remoteness of the real analogy between recording laws and marketability laws of the second type gives the court an option, for it need not probe beyond the intermediate purpose to seek the law's justification. Apparently, the New York court was content to accept the intermediate purpose as ultimately controlling, and on this basis rejected the analogy between the New York law and recording acts.

${ }^{28} 15$ N.Y.2d at 371,207 N.E.2d at 185,259 N.Y.S.2d at 135 (dictum).

${ }^{20}$ See Lewis v. State, 32 Ariz. 182, 256 Pac. 1048 (1927); Wright v. DeFatta, 142 So. 2d 489 (La. Ct. App. 1962), aff'd, 244 La. 251, 152 So. 2d 10 (1963).

3015 N.Y.2d at $369-70,207$ N.E.2d at 184, 259 N.Y.S.2d at 134. The court cites as authority: Curtis v. Whitney, 13 Wall. (80 U.S.) 68 (1871); McCracken v. Hayward, 2 How. (43 U.S.) 608 (1844); Jackson ex dem. Hart v. Lamphire, 3 Pet. (28 U.S.) 280 (1830); Leonard v. Harris, 147 App. Div. 458, 131 N.Y. Supp. 909, aff'd, 211 N.Y. 511, 105 N.E. 1089 (1914); Fitzpatrick v. Boylan, 57 N.Y. 433 (1874) (see dissenting opinion of Commissioner Dwight, id. at 437).

31 N.Y.2d at 370,207 N.E.2d at 184,259 N.Y.S.2d at 134 . See cases cited note 30 supra. A thorough analysis of precedents cited by the New York court indicates that they may not support the court's conclusion. Perhaps the most frequently cited of these cases, and the one upon which Miles appearcd to most heavily rely, was Jackson ex dem. Hart v. Lamphire, supra note 30 . In that case, the United States Supreme Court held that states may constitutionally cnact retroactively effective recording acts and statutes of limitation, based on "reasons of sound policy." Id. at 290. As an example of such legislation, the Court cited a New York law [Recording Act of January, 1794, N.Y. Laws 1789-1796, at 480] and noted that the statute rwas based on policy considerations sufficient to support its constitutionahity. Jackson ex dem. Hart v. Lamphire, supra note 30, at 290.

This act recited three reasons justifying its enactment: to achieve a remedy for the uncertain state of titles to certain lands in the state, to detect the persons who 
vention of frauds which constitutionally justify recording laws, the persuasiveness of the Miles decision will be impaired.

The court's second conclusion, that section 345 necessarily requires registration by unascertained persons and thus violates a constitutional restriction imposed upon statutes of limitation, ${ }^{32}$

had been perpetrating frauds in the sale of those lands, and to prevent such frauds in the future.

The Miles court, in relying on Lamphire, would seem not to have considered, al. though it may have rejected by implication, the first of these three policy justifications-the economic interest in remedying uncertainty as to the state of titles to land. However, there is no indication that the Supreme Court in Lamphire was excluding this policy as one which may support the validity of such legislation.

The other opinions cited by the Miles court were also relied on as support for the sweeping generalization that "except for the protection of third parties, ... [these cases] would indicate that the recording acts would impair the obligation of contracts and deprive persons of property without due process of law." 15 N.Y.2d at 371, 207 N.E.2d at 185, 259 N.Y.S.2d at 135. Here again, careful consideration of these cases indicates that they do not necessitate the conclusion that recording acts are justified only by the policy of protecting third persons against fraud.

In McCracken v. Hayward, supra note 30, the Supreme Court did no more in this respect than rely on Jackson ex dem. Hart v. Lamphire, supra note 30 , for the proposition that not "all state legislation on existing contracts is necessarily repugnant to the constitution." McCracken v. Hayward, supra note 30, at 613. This case therefore does not in any way refute the fact that policies other than the protection of third persons may justify such statutes.

In Curtis v. Whitney, supra note 30 , the Supreme Court held valid a Wisconsin statute requiring the purchaser of a tax title to give notice to occupiers of the premises before taking the title. The Court articulated the criterion justifying such retroactive legislation to be "the public good," $i d$. at 71 ; and although the decision was rendered in a case involving legislation protecting third parties (those about to lose their land for failure to pay taxes), the Court did not attempt to restrict the scope of the words to that element alone.

The Miles court also cites the dissenting opinion by Commissioner Dwight in Fitzpatrick v. Boylan, supra note 30. Dwight was arguing for retrospective application of a law regarding mechanics' liens. His argument was that retrospective legislation was valid if based generally on "reasons of sound policy" (id. at 443, emphasis supplied by Dwight, quoting from Jackson ex dem. Hart v. Lamphire, supra note 30), and that the policy of the new law sought to be applied was the termination of liens which, if not exercised or enforced within a reasonable time, put too great a burden on land.

Thus, although there are grounds for distinguishing these decisions on their facts as the New York court did in the Miles case, that court's conclusions as to the reason. ing and import of these cases does not appear to be wholly justified.

${ }^{32}$ Statutes of limitation must not cut off rights abruptly, but must allow time for holders of interests effected at the time of the passage of the act to preserve their interests by conforming to the Jaw's requirements. Wilson v. Iseminger, 185 U.S. 55, 62 (1902). In this case the Supreme Court adopted a due process-type test stating that "a statute could not bar the existing rights of claimants without affording this opportunity; if it should attempt to do so, it would not be a statute of limitations, but an unlawful attempt to extinguish rights arbitrarily, whatever might be the purport of its provisions. Ibid.

It is interesting to note the policy being promoted by the statute of limitations in that case. The statute was specifically enacted to extinguish ground rents-an estate in land under Pennsylvania law-unless a notice of payment was filed every twenty- 
is likewise open to question. Historically, New York was one of the few jurisdictions in which certain future interests, including "possibilities of reverter," were deemed to pass by representation rather than by descent. ${ }^{33}$ If this doctrine is strictly applied in the Miles case, the conclusion reached by the court may be justified. The owner of such an interest would be unknown until the "possibility" matured. At that time the original grantor's representatives would be determined, and the estate would vest in them. But prior to the breach, the representatives would be unknown, and would have no alienable or devisable rights or interests. ${ }^{34}$ However, two factors cast doubt on the validity of such application in the Miles case. The first arises out of the narrowing effect on the doctrine of representation caused by the decision in Nichols $v$. Haehn, ${ }^{35}$ a 1959 Appellate Division case which expressly held possibilities of reverter to be fully alienable and devisable. ${ }^{36}$ On the basis of this decision, it appears that the defendants in the Miles case did have a recognizable interest capable of being preserved. The second factor stems from a known exception to the "representation" doctrine. Although "possibilities of reverter" may not be alienable or devisable, they are "releasable" to the owner of the possessory in-

one years. In summarizing the problem, the court took note of the fact that ancient ground rents, which in all probability have been extinguished, frequently remain on the public record as blemishes on the title to land and cannot be removed since no living person has knowledge of them. Id. at 60 .

${ }^{33}$ Upington v. Corrigan, 151 N.Y. 143, 45 N.E. 359 (1896). See Simes, Future INTERESTS $\$ 34$, at 111-12 (1951). Simes employs the following example to contrast the passing of a reverter by representation or descent: "A conveys Blackacre 'to $B$ and his heirs so long as the premises are used for residence purposes,' thus creating a determinable fee in $B$ and a possibility of reverter in A. Thereafter A dies intestate leaving, as his only heir, his son $\mathrm{X}$. Then $\mathrm{X}$ dies, leaving as his only heir, his wife $W$. Subsequently the land ceases to be used for residence purposes, and the possibility of reverter becomes a possessory interest. If $A$ had died at the time the possibility of reverter became possessory, his heir would have been his brother $Y$. Thus, it is held that $Y$ and not $W$ takes the land. This is because descent must be traced from $A, \ldots$ and $W$, being unrelated to $A$ cannot be his heir." Id. at 111 .

st See note 33 supra.

${ }^{38} 8$ App. Div. 2d 405, 411, 187 N.Y.S.2d 773, 774 (1959). The court noted that although Upington v. Corrigan, 151 N.Y. 143, 45 N.E. 359 (1896), framed its dis. cussion in terms of "possibilities of reverter," the interest actually involved in that case was not what is commonly known as a possibility of reverter, but rather what is called a power of termination. Thus the court felt that although some authors had accepted Upington v. Corrigan, supra, at face value, that decision was not true authority for the case where a true possibility of reverter was involved.

${ }^{30}$ This decision established New York's acceptance of the general rule regarding possibilities of reverter. In the absence of a statutory basis, most courts hold that rights of entry are inalienable. See generally 2 Powell, REAL ProperTy $\$ \S 281-82$, 284 (1950); SIMEs, op. cit. supra note 33, §§ 33-35. 
terest. $^{37}$ It might be contended that if these interests are releasable, there is no valid reason that they are not registerable. ${ }^{38}$

Even if the New York court is correct in its conclusion that marketability legislation cannot be upheld on the same theory as recording acts, the persuasiveness of the Miles opinion is still not established. The court made little attempt to discuss the important issue of whether or not the statute would be supportable on any other theory..$^{39}$ The police power may be invoked for more than the singular purpose of preventing frauds. Generally, a valid use of the police power requires a substantial relationship of the challenged legislation to the public health, safety, morals or general welfare. ${ }^{40}$ Previous decisions have established that economic interests are, or may be, sufficiently related to the general welfare to support state action under the police power. .1 $^{1}$ In other states where the validity of

${ }^{37}$ Trustees of Calvary Presbyterian Church v. Putnam, 249 N.X. 111, 116, 162 N.E. 601, 603 (1928); Atkins v. Gillespie, 156 Tenn. 137, 141, 299 S.W. 776, 777-78 (1927); 2. Powelt op. cit. supra note $36, \S 281$.

${ }^{38}$ One policy expressed by the court in Trustees of Calvary Presbyterian Church v. Putnam, supra note 37, was that certain interests in land are "strictly construed because they tend to destroy estates. Public interests dictate that real property shall be readily transferable and that titles shall be marketable." Id. at 115, 162 N.E. at 602. Thus, the court allowed a potential representative who technically had no interest at the time not only to release whatever interest he might in the future acquire, but also, by the same act and in the same manner, to bar the rights of future representatives.

It may be contended that if such a potential representative has the power to destroy the rights of future representatives for his sole benefit, he should have the power to preserve them. In that case he is also preserving his own interests, since he may turn out to be the representative when the condition is breached and the reverter matures. The potential future representative is better protected under the recording law than under the doctrine of release.

If the present representative should choose to relinquish his interest, and necessarily the interests of potential future representatives, such future representatives are no more disadvantaged by the recording requirements of the marketability law than by the doctrine of release.

${ }^{30}$ See 15 N.Y.2d at $371-74,207$ N.E.2d at 185-87, 259 N.Y.S.2d at 135-37.

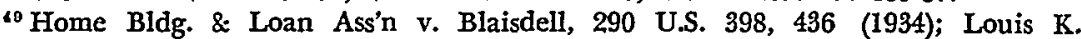
Liggett Co. v. Baldridge, 278 U.S. 105, 111-12 (1928); People v. Title \& Mortgage Guar. Co., 264 N.Y. 69, 84, 190 N.E. 153, 157 (1934).

In the latter case it was stated that "legislation which impairs the obligation of a contract or otherwise deprives a person of his property can be sustained only when enacted for the promotion of the general good of the public, the protection of the lives, health, morals, comfort, and general welfare of the people and when the means adopted to secure that end are reasonable. ... Even the economic interests of the state may justify the exercise of its continuing and dominant protective power notwithstanding interference with contracts." People v. Title \& Mortgage Guar. Co., supra at 84, 190 N.E. at 157 (quoting from Home Bldg. \& Loan Ass'n v. Blaisdell, supra, decided less than three months earlier).

"See Home Bldg. \& Loan Ass'n v. Blaisdell, supra note 40; People v. Title \& Mortgage Guar. Co., supra note 40. 
marketable title legislation has been upheld, the courts have largely based their decisions on this aspect of the police power; ${ }^{42}$ further, it was this element on which the lower court in the Miles case based its decision upholding the validity of the New York law. ${ }^{43}$ Yet, in reversing the lower court decision, the Court of Appeals did not discuss economic welfare as a possible basis for such legislation. Instead it focused on the burden of recording imposed by the marketability law and apparently evaluated the statute on the assumption that this particular burden can only be imposed in specified situations. ${ }^{44}$ This attitude ignores the frequently stated proposition that a reasonable burden may be imposed if it will accomplish an acceptable public goal. ${ }^{45}$ By ignoring the issue of economic interest, the Miles decision negatively implies that such interest is not a sufficient basis for invocation of the police power or for the imposition of the burden of recording to preserve ownership of certain interests. Because of this implication, the Miles case may lack persuasiveness in those jurisdictions in which it is recognized that police power may be exercised for valid economic reasons.

42 See Trustees of Schools of Township No. 1 v. Batdorf, 6 Ill. 2d 486, 493, 130 N.E.2d I1I, 114 (1955); Tesdell v. Hancs, 248 Iowa 742, 749, 82 N.W.2d 119, 123 (1957); Wichclman v. Messner, 250 Minn. 88, 99, 83 N.W.2d 800,805 (1957).

${ }^{48}$ Board of Educ. v. Mills, 18 App. Div. 2d 87, 93, 238 N.X.S.2d 766, 772 (1963). Sce text accompanying note I2 supra.

415 N.Y.2d at $370-71,207$ N.E.2d at I85, 259 N.Y.S.2d at 134-35. Sec text accompanying note 31 supra.

${ }^{t 5}$ See, e.g., Clason v. Indiana, 306 U.S. 439, 443 (1939); Home Bldg. \& Loan Ass'n v. Blaisdell, 290 U.S. 398, 438 (1934). In the Blaisdell casc, supra, the Supreme Court stated that the "question is not whether the legislative action affects contracts incidentally, or directly or indirectly, but whether the legislation is addressed to a legitimate end and the measures taken are reasonable and appropriate to that end." Id. at 438 . 